\title{
SIFAT FISIS DAN MEKANIS KAYU JATI SUPER DAN JATI LOKAL DARI BEBERAPA DAERAH PENANAMAN
}

\author{
(Physical and Mechanical Properties of Super and Local Teak Woods \\ Originated from Several Plantation Areas)
}

\author{
Oleh/By : \\ Nurwati Hadjib, Mohammad Muslich \& Ginuk Sumarni ${ }^{1)}$
}

\begin{abstract}
Research on properties of local and super teak woods (Tectona grandis L.f.) grown in Binjai, Maros, Parung, Panajam, Kutai, Lampung, Bengkulu and Palembang were done to investigate the effect to its physical and mechanical characteristics. The result showed that specific gravity of super teak wood is higher than local teak. wood. The highest specific gravity was found on super teak wood from Binjai and the lowes on that from Maros, Sulawesi. Type of teak wood, local and super, are significantly affected the green specific gravity, but plantation areas do not affect the specific gravity. Local teak wood from Palembang is the strongest among the woods tested, followed by super teak wood from Lampung, local teak wood from Kutai, super teak wood Bengkulu, super teak wood from Kutai, local teak wood from Binjai, super teak wood from Palembang, local teak wood from Lampung, local teak wood from Sulawesi and the weakest is super teak wood from Sulawesi. The types of teak wood only affect the compression parallel to the grain, while plantation areas effect modulus elasticity and modulus of rupture. Refering to Indonesian Wood Strength Classification, all teak woods tested are grouped as class III-IV.
\end{abstract}

Keyword: Teak, wood, local, super, physics, mechanics

\begin{abstract}
ABSTRAK
Penelitian sifat fisis dan mekanis kayu jati (Tectona grandis L.f.) jenis lokal dan super dari daerah Binjai, Maros, Parung, Panajam, Kutai, Lampung, Bengkulu dan Palembang bertujuan untuk melihat perbedaan karakteristik sifat fisis dan mekanis kayunya. Hasil penelitian menunjukkan bahwa rata-rata berat jenis (BJ) kayu jati super lebih tinggi daripada kayu jati lokal, sedangkan BJ tertinggi pada kayu jati super adalah dari Binjai dan terendah dari Maros. Jenis jati lokal dan super berpengaruh nyata terhadap berat jenis basah kayu tersebut, sedangkan lokasi penanaman jati tidak memberikan pengaruh yang nyata terhadap berat jenis. Kayu yang terkuat adalah jati lokal dari Palembang, diikuti berturut-turut kayu jati super dari Lampung, jati lokal dari Kutai, jati super dari Bengkulu, jati super dari Kutai, jati lokal dari Binjai, jati super dari Parung, jati super dari Binjai, jati supr dari Palembang, jati lokal dari Lampung,
\end{abstract}

${ }^{17}$ Peneliti pada Pusat Penelitian dan Pengembangan Hasil Hutan, Bogor 
jati lokal dari Sulawesi dan yang terendah jati super dari Sulawesi. Perbedaan BJ tersebut berpengaruh nyata pada kekakuan dan keteguhan tekan sejajar serat, sedangkan lokasi tanaman berpengaruh nyata terhadap kekakuan dan kekuatan patahnya. Kayu jati yang diteliti tergolong kelas kuat III-IV.

Kata kunci: Kayu jati, lokal, super, fisis, mekanis

\section{PENDAHULUAN}

Kayu merupakan produk biologi yang serba guna dan telah lama dikenal dan dimanfaatkan, baik untuk alat rumah tangga, senjata maupun sebagai bahan bangunan. Sebagai bahan bangunan kayu masih banyak digunakan karena harganya relatif murah dibanding bahan bangunan lainnya. Di samping mudah untuk dikerjakan dan penampilannya dekoratif, kayu merupakan bahan yang bisa diperbaharui (renewable).

Pasokan kayu yang berasal dari hutan alam sebagai penghara industri semakin berkurang. Saat ini banyak ditanam jati cepat tumbuh yang diharapkan kayunya dapat digunakan sebagai kayu pertukangan, pengganti kayu dari hutan alam. Sementara kayu yang berasal pohon cepat tumbuh cenderung mempunyai sifat kurang baik. Menurut Martawijaya (1990), kayu berasal dari hutan alam mempunyai sifat dasar yang lebih baik bila dibandingkan dengan kayu hutan tanaman. Hal ini kemungkinan berlaku bagi kayu jati cepat tumbuh.

Kayu jati (Tectona grandis) di Indonesia telah ditanam sejak jaman Belanda dan telah dimanfaatkan secara luas oleh masyarakat terutama untuk bahan bangunan dan mebel. Bahkan di Jawa tanaman tersebut telah menjadi kelas perusahaan tersendiri sejak jaman Belanda. Penelitian mengenai jati telah banyak dilakukan baik yang bertujuan untuk meningkatkan mutu tanaman maupun nilai tambah dari kayu tersebut. Dengan kemajuan teknologi yang berkembang akhir-akhir ini, perbanyakan bibit jati yang semula hanya mengandalkan biji, dikembangkan dengan cara kultur jaringan atau lebih dikenal dengan "tissue culture". Tujuan dari kultur jaringan adalah untuk memproduksi bibit secara cepat, dalam jumlah banyak dari bibit tanaman yang dinilai mempunyai sifat baik dan unggul (Herawan dan Rina, 1996). Kayu jati super dalam tulisan ini adalah kayu jatihasil kultur jaringan dan telah dikembangkan di Indonesia.

Penelitian ini bertujuan untuk melihat perbedaan sifat fisis dan mekanis antara kayu jati lokal dengan jati super yang berasal dari beberapa daerah. Sifat yang diteliti adalah : berat jenis, keteguhan lentur statis (keteguhan pada batas proporsi, keteguhan patah dan modululus elastisitas), keteguhan tekan sejajar serat dan kekerasan ujung pada sisi (radial dan tangensial).

Hasil penelitian ini diharapkan dapat digunakan sebagai bahan pertimbangan bagi pengambil keputusan dalam pengembangan dan pemanfaatan jati super.

\section{BAHAN DAN METODE}

\section{A. Bahan}

Bahan yang digunakan adalah kayu jati (Tectona grandis L. f.) hutan tanaman yang berasal dari beberapa lokasi seperti pada Tabel 1. Rata-rata umur pohon dan diameter batang setinggi 
dada pada saat diambil relatif sama. Dari setiap lokasi diambil masing-masing satu pohon yang mewakili jati super dan jati lokal. Bagian pohon yang diambil yaitu batang bebas cabang, dengan membedakan bagian pangkal, tengah dan ujung seperti Gambar 1 .

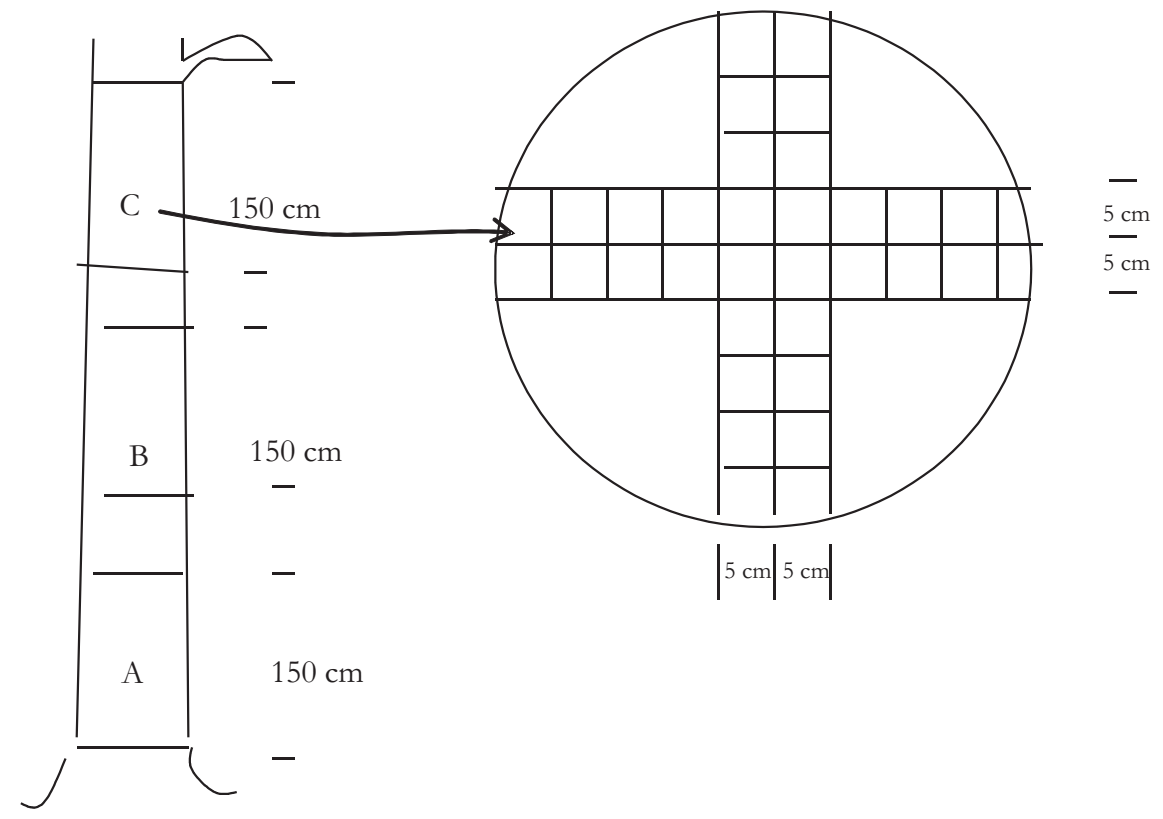

Gambar 1. Pola pengambilan contoh uji

Figure 1. Cutting pattern of wood sampling

Tabel 1. Asal contoh kayu jati yang diuji

Table 1. Plantation area of teak wood tested

\begin{tabular}{|c|l|c|c|c|}
\hline No. & \multicolumn{1}{|c|}{$\begin{array}{c}\text { Asal } \\
\text { (Originated) }\end{array}$} & $\begin{array}{c}\text { Jenis } \\
(\text { Type })\end{array}$ & $\begin{array}{c}\text { Umur (Age), } \\
\text { th (year) }\end{array}$ & $\begin{array}{c}\text { Diameter, } \\
\mathrm{cm}\end{array}$ \\
\hline 1. & Binjai, Sumatra Utara & $\mathrm{S}$ & 5 & 19,8 \\
& Binjai, Sumatra Utara & $\mathrm{L}$ & 5 & 14,7 \\
& Maros, Sulawesi Selatan & $\mathrm{S}$ & 4 & 10,8 \\
3. & Parung, Jawa Barat & $\mathrm{L}$ & 4 & 8,4 \\
4. & Panajam, Kalimantan Timur & $\mathrm{S}$ & 5,4 & 19,6 \\
& Kutai Kertanegara, Kalimantan Timur & $\mathrm{L}$ & 6 & 11,5 \\
5. & Lampung & $\mathrm{S}$ & 5 & 6,1 \\
& & $\mathrm{~S}$ & 5 & 13,7 \\
6 & Bengkulu & $\mathrm{L}$ & 4 & 10,9 \\
& Palembang & $\mathrm{S}$ & 5 & 13,1 \\
& & $\mathrm{~S}$ & 7 & 20,9 \\
\hline
\end{tabular}

Keterangan (Remarks) : S : Super ; L : Lokal (Local) 


\section{B. Alat}

Alat yang digunakan dalam percobaan ini adalah gergaji belah, gergaji potong, mesin serut, alat pengukur panjang (penggaris, meteran, dial caliper), timbangan, gelas piala, desikator, oven dan universal testing machine.

\section{Metode}

Pengujian sifat fisis dan mekanis kayu dilakukan sesuai dengan standar ASTM D.143-94 (Anonim, 1995). Banyaknya contoh uji yang diambil dari setiap pohon disesuaikan dengan besarnya diameter pohon yang diambil. Pengujian sifat fisis dan mekanis yang dilakukan meliputi berat jenis (berdasar berat kering oven dan volume basah), keteguhan lentur statis (tegangan pada batas proporsi dan tegangan patah serta modulus elastisitas), keteguhan tekan sejajar serat, kekerasan (ujung, sisi radial dan tangensial).

\section{Analisis Data}

Analisis data dilakukan terhadap nilai rata-rata hasil pengujian dan pengamatan sifat fisis dan mekanis jati lokal dan jati super dari berbagai daerah.

Rancangan percobaan yang digunakan adalah rancangan acak lengkap dengan faktor utama kombinasi faktor $(\mathrm{T})$ tipe jati (lokal dan super) serta daerah penanaman ( $\mathrm{t} 1=$ Binjai lokal, $\mathrm{t} 2=$ Binjai super, $\mathrm{t} 3=$ Sulawesi lokal, $\mathrm{t} 4=$ Sulawesi super, $\mathrm{t} 5=$ Parung super, $\mathrm{t} 6=\mathrm{Kaltim}$ lokal, $\mathrm{t} 7=$ Kaltim super, $\mathrm{t} 8=$ Lampung lokal, $\mathrm{t}$ 9=Lampung super, $\mathrm{t} 10=$ Bengkulu super, t11=Palembang lokal, t12 =Palembang super. Ulangan $(\mathrm{R})=2-10$ kali sesuai besarnya diameter pohon.

\section{HASIL DAN PEMBAHASAN}

\section{A. Sifat Fisis Kayu}

Nilai rata-rata berat jenis (BJ) kayu jati yang diteliti dapat dilihat pada Tabel 2. Pada Tabel 2 dapat diketahui bahwa berat jenis tertinggi terdapat pada jati super dari Lampung $(0,65)$ diikuti berturut-turut jati super dari Kutai $(0,58)$, jati lokal Kutai $(0,58)$, jati super Bengkulu $(0,57)$, jati super Sulawesi $(0,57)$, jati lokal Binjai $(0,57)$, jati lokal Palembang $(0,56)$, jati super Parung (0,56), jati lokal Lampung $(0,56)$, jati super Binjai $(0,54)$, jati super Palembang $(0,51)$ dan terendah jati lokal dari Sulawesi $(0,49)$.

Rata-rata berat jenis kayu jati super lebih tinggi jika dibandingkan dengan kayu jati lokal. Pada Gambar 2, juga terlihat bahwa sebagian besar kerapatan (perbandingan berat dan volume kering udara) kayu jati super lebih tinggi jika dibandingkan kayu jati lokal. Kerapatan tertinggi terdapat pada kayu jati super dari Lampung $(0,65)$ diikuti berturut-turut jati super dari Kutai $(0,58)$ Bengkulu $(0,57)$, Maros $(0,57)$, Parung $(0,56)$, Binjai $(0,54)$ dan terendah dari Palembang $(0,51)$. Sedangkan jati lokal tertinggi terdapat pada jati asal Kutai $(0,58)$, diikuti berturut-turut jati lokal Binjai $(0,57)$, Palembang $(0,56)$, Lampung $(0,56)$ dan terendah dari Sulawesi $(0,49)$. 
Tabel 2. Nilai rata-rata berat jenis kayu jati yang diteliti Table 2. Average of specific gravity of teak wood tested

\begin{tabular}{|c|c|c|c|c|c|c|c|c|}
\hline \multirow{2}{*}{\multicolumn{2}{|c|}{$\begin{array}{l}\text { Asal daerah } \\
\text { (Source of plant) }\end{array}$}} & \multicolumn{2}{|c|}{$\begin{array}{c}\text { Kadar air } \\
\text { (Moisture content), } \\
\%\end{array}$} & \multicolumn{5}{|c|}{ Berat jenis berdasar (Specific gravity based on) } \\
\hline & & \multirow{2}{*}{$\begin{array}{l}\begin{array}{r}\text { Basah } \\
\text { (green) }\end{array} \\
83,09\end{array}$} & $\begin{array}{l}\text { K. udara } \\
\text { (Airdry) }\end{array}$ & \multirow{2}{*}{$\frac{\mathrm{Bb} / \mathrm{Vb}}{0,85}$} & \multirow{2}{*}{$\begin{array}{c}\mathrm{Bku} / \mathrm{Vku} \\
0,57\end{array}$} & \multirow{2}{*}{$\frac{\mathrm{Bko} / \mathrm{Vko}}{0,51}$} & \multirow{2}{*}{$\frac{\mathrm{Bko} / \mathrm{Vku}}{0,48}$} & \multirow{2}{*}{$\frac{\mathrm{Bko} / \mathrm{Vb}}{0,46}$} \\
\hline Binjai & $\mathrm{L}$ & & 16,86 & & & & & \\
\hline & S & 99,44 & 16,92 & 0,88 & 0,54 & 0,48 & 0,46 & 0,44 \\
\hline \multirow[t]{2}{*}{ Sulawesi } & $\mathrm{L}$ & 119,07 & 17,16 & 0,89 & 0,49 & 0,43 & 0,42 & 0,41 \\
\hline & $\mathrm{S}$ & 76,51 & 17,55 & 0,81 & 0,57 & 0,48 & 0,45 & 0,42 \\
\hline Parung & S & 92,69 & 17,36 & 0,87 & 0,56 & 0,50 & 0,49 & 0,47 \\
\hline \multirow[t]{2}{*}{ Kutai } & $\mathrm{L}$ & 80,66 & 16,84 & 0,86 & 0,58 & 0,52 & 0,51 & 0,48 \\
\hline & S & 53,07 & 16,91 & 0,73 & 0,58 & 0,53 & 0,49 & 0,47 \\
\hline \multirow[t]{2}{*}{ Lampung } & L & 68,85 & 16,70 & 0,78 & 0,56 & 0,50 & 0,45 & 0,43 \\
\hline & S & 66,86 & 16,44 & 0,88 & 0,65 & 0,59 & 0,56 & 0,54 \\
\hline Bengkulu & S & 63,84 & 16,75 & 0,77 & 0,57 & 0,52 & 0,51 & 0,49 \\
\hline \multirow[t]{2}{*}{ Palembang } & L & 71,89 & 16,13 & 0,78 & 0,56 & 0,51 & 0,50 & 0,48 \\
\hline & S & 124,92 & 16,24 & 0,94 & 0,51 & 0,46 & 0,43 & 0,41 \\
\hline
\end{tabular}

Keterangan (Remarks) : L = Lokal (Loca), S = Super; B = Berat (Weight, gram); b = Basah (Green); ku = Kering udara $\left(\right.$ Airdry) $; \mathrm{ko}=\operatorname{Kering}$ oven $($ Ovendry $) ; \mathrm{V}=$ Volume $\left(\mathrm{cm}^{3}\right)$

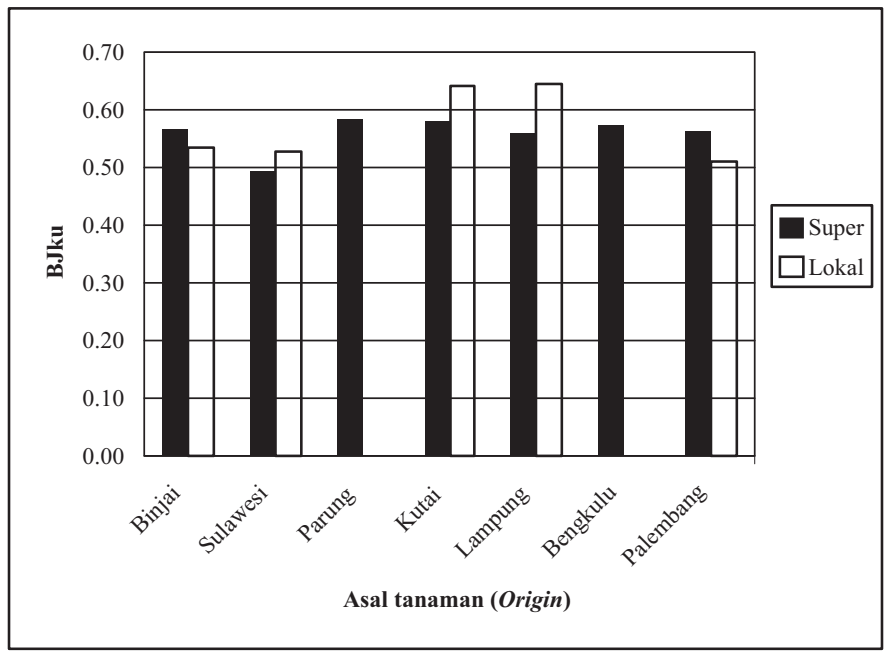

Gambar 2. Histogram berat jenis kering udara kayu jati lokal dan super yang diteliti Figure 2. Hystogram of air dry specific gravity of local and super teak wood tested 
Menurut Martawijaya et al.(1981), rata-rata nilai kerapatan kayu jati adalah 0,67. Nilai rata-rata kerapatan kayu jati yang diteliti cenderung lebih rendah, karena umurnya masih muda. Haygreen dan Bowyer (1982), menunjukkan hubungan antara umur dan berat jenis dan tempat tumbuh. Disebutkan bahwa semakin bertambah umur pohon, semakin tinggi berat jenis kayu tersebut. Dikatakan pula bahwa kayu yang tumbuh di daerah yang lebih subur, akan lebih cepat tumbuh dan mempunyai kerapatan yang lebih rendah dibanding yang tumbuh di tempat yang kurang subur.

Tabel3. Sidik ragam pengaruh perlakuan terhadap berat jenis kayu jati yang diteliti Table 3. Analysis of variance of type and source of plant effect to specific gravity of teak wood tested

\begin{tabular}{|c|c|c|c|c|c|c|c|}
\hline \multirow{3}{*}{$\begin{array}{l}\text { Sumber keragaman } \\
\text { (Source of variance) }\end{array}$} & \multirow{3}{*}{$\begin{array}{l}\mathrm{Db} \\
(d f)\end{array}$} & \multicolumn{6}{|c|}{ Kuadrat tengah (Mean square) } \\
\hline & & \multirow{2}{*}{$\begin{array}{l}\mathrm{Bb} / \mathrm{Vb} \\
\mathrm{Wg} / \mathrm{Vg}\end{array}$} & \multirow{2}{*}{$\begin{array}{c}\mathrm{Bku} / \mathrm{Vku} \\
\mathrm{Wa} / \mathrm{Va}\end{array}$} & \multirow{2}{*}{$\begin{array}{l}\mathrm{Bko} / \mathrm{Vko} \\
\mathrm{Wo} / \mathrm{Vo}\end{array}$} & \multirow{2}{*}{$\begin{array}{l}\mathrm{Bo} / \mathrm{Vb} \\
\mathrm{Wg} / \mathrm{Vo}\end{array}$} & \multicolumn{2}{|c|}{ Kadar air $(M C)$} \\
\hline & & & & & & $\begin{array}{l}\text { Basah } \\
\text { (Green) }\end{array}$ & $\begin{array}{c}\text { Kering } \\
\text { udara } \\
\text { (Airdry) }\end{array}$ \\
\hline Perlakuan (Treatment) & 11 & 0.0922 & 0.0423 & 0.0338 & 0.0291 & 2820.4003 & 11 \\
\hline Galat (Error) & 46 & 0.0855 & 0.0328 & 0.0264 & 0.0216 & 1387.4702 & 46 \\
\hline Total & 57 & & & & & & 57 \\
\hline
\end{tabular}

Dari Tabel 3 ternyata baik jati super maupun jati lokal yang berasal dari beberapa daerah yang diteliti tidak menyebabkan perbedaan berat jenis kayu.

\section{B. Sifat Mekanis Kayu}

Rata-rata sifat kekuatan kayu jati super dan lokal yang diteliti disajikan pada Tabel 4 dan Gambar 2, 3 dan 4. Pada Tabel dan Gambar tersebut terlihat bahwa secara keseluruhan, kayu terkuat (MOR) adalah jati lokal dari Palembang $\left(558,30 \mathrm{~kg} / \mathrm{cm}^{2}\right)$, jati super dari Lampung $\left(528,74 \mathrm{~kg} / \mathrm{cm}^{2}\right)$, jati lokal dari Kutai $\left(502,32 \mathrm{~kg} / \mathrm{cm}^{2}\right)$, jati super dari Bengkulu $(469,91$ $\left.\mathrm{kg} / \mathrm{cm}^{2}\right)$, jati super dari Kutai $\left(445,11 \mathrm{~kg} / \mathrm{cm}^{2}\right)$, jati lokal dari Binjai $\left(437,13 \mathrm{~kg} / \mathrm{cm}^{2}\right)$, jati super dari Parung $\left(414,44 \mathrm{~kg} / \mathrm{cm}^{2}\right)$, jati super dari Binjai $\left(409,78 \mathrm{~kg} / \mathrm{cm}^{2}\right)$, jati super dari Palembang $\left(402,62 \mathrm{~kg} / \mathrm{cm}^{2}\right)$, jati lokal dari Lampung $\left(379,28 \mathrm{~kg} / \mathrm{cm}^{2}\right)$, jati lokal dari Sulawesi $(308,68$ $\left.\mathrm{kg} / \mathrm{cm}^{2}\right)$ dan yang terendah jati super dari Sulawesi $\left(243,74 \mathrm{~kg} / \mathrm{cm}^{2}\right)$.

\section{Sifat kekuatan kayu jati lokal}

Secara rinci keteguhan patah (MOR) jati lokal tertinggi terdapat pada jati yang berasal dari Palembang $\left(558,30 \mathrm{~kg} / \mathrm{cm}^{2}\right)$, diikuti berturut-turut jati lokal dari Kutai $\left(502,33 \mathrm{~kg} / \mathrm{cm}^{2}\right)$, Binjai $\left(437,13 \mathrm{~kg} / \mathrm{cm}^{2}\right)$, Lampung $\left(379,28 \mathrm{~kg} / \mathrm{cm}^{2}\right)$ dan terendah jati dari Sulawesi $\left(308,68 \mathrm{~kg} / \mathrm{cm}^{2}\right)$. Sedangkan jati dari Parung dan Bengkulu tidak ada data.

Modulus elastisitas (MOE) tertinggi terdapat pada jati lokal berasal dari Kutai (53253,32 $\left.\mathrm{kg} / \mathrm{cm}^{2}\right)$, Lampung $\left(46328,91 \mathrm{~kg} / \mathrm{cm}^{2}\right)$, Palembang $\left(45520,29 \mathrm{~kg} / \mathrm{cm}^{2}\right)$, Binjai $(42330,58$ $\mathrm{kg} / \mathrm{cm}^{2}$ ) dan terendah terdapat pada jati lokal berasal dari Sulawesi $26534.21 \mathrm{~kg} / \mathrm{cm}^{2}$ ). 


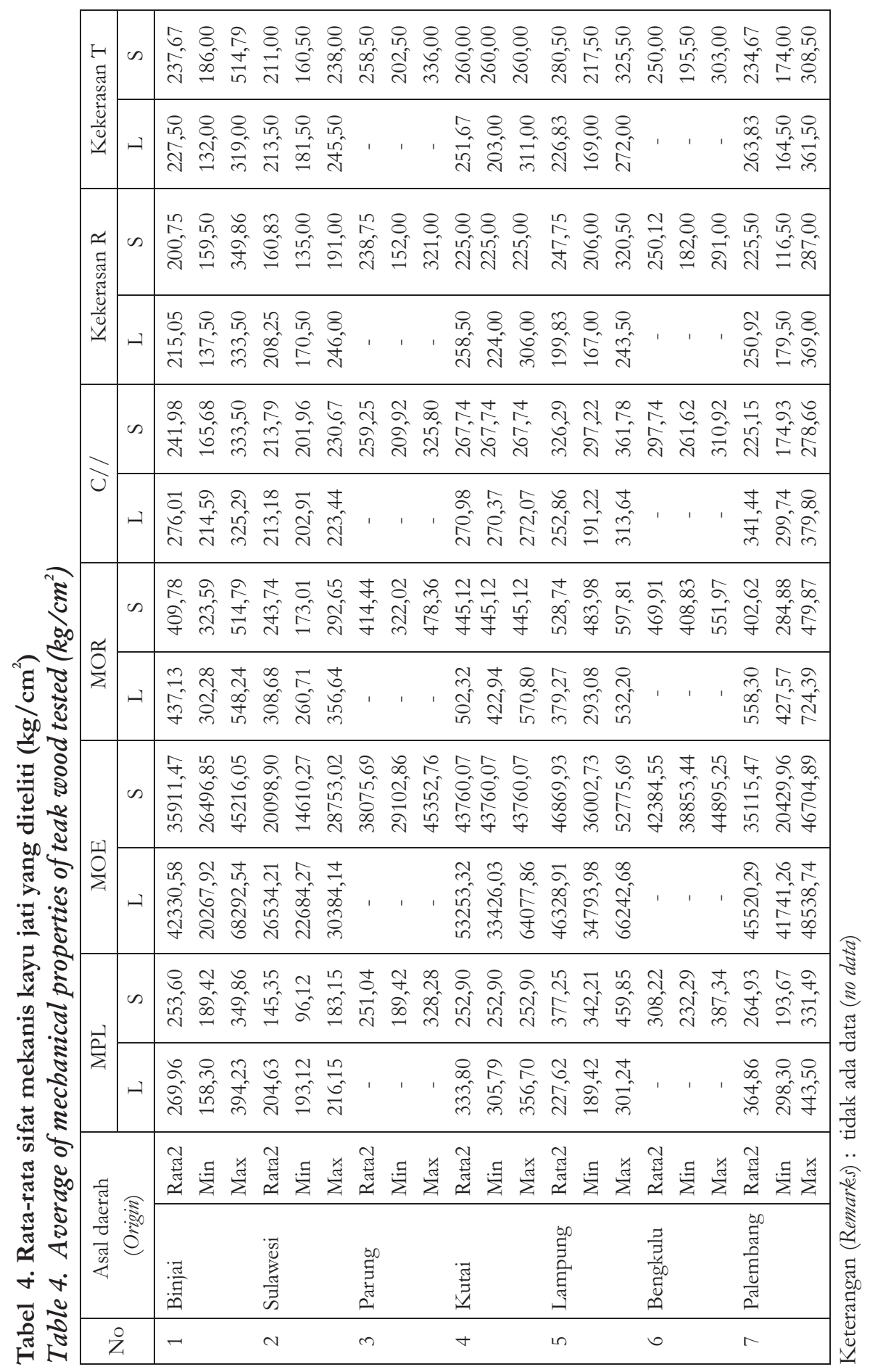


Kekerasan pada bidang tangensial tertinggi pada jati lokal berasal dari Kutai (258,50 $\left.\mathrm{kg} / \mathrm{cm}^{2}\right)$, Palembang $\left(250,92 \mathrm{~kg} / \mathrm{cm}^{2}\right)$, Binjai $\left(215,05 \mathrm{~kg} / \mathrm{cm}^{2}\right)$, Sulawesi $\left(208,25 \mathrm{~kg} / \mathrm{cm}^{2}\right) \mathrm{dan}$ terendah berasal dari Lampung $\left(199,83 \mathrm{~kg} / \mathrm{cm}^{2}\right)$.

\section{Sifat kekuatan kayu jati super}

Tegangan pada batas proporsi (MPL) tetinggi berasal dari Lampung $\left(377,25 \mathrm{~kg} / \mathrm{cm}^{2}\right)$, Bengkulu $\left(308,22 \mathrm{~kg} / \mathrm{cm}^{2}\right)$, Palembang $\left(264,93 \mathrm{~kg} / \mathrm{cm}^{2}\right)$, Binjai $\left(253,60 \mathrm{~kg} / \mathrm{cm}^{2}\right)$ dan terendah dari Kutai $\left(252,90 \mathrm{~kg} / \mathrm{cm}^{2}\right)$. Modulus elastisitas (MOE) tertinggi terdapat pada jati super dari Lampung $\left(46869,93 \mathrm{~kg} / \mathrm{cm}^{2}\right)$, Kutai $\left(43760,07 \mathrm{~kg} / \mathrm{cm}^{2}\right)$, Bengkulu $\left(42384,55 \mathrm{~kg} / \mathrm{cm}^{2}\right)$, Parung $\left(38075,69 \mathrm{~kg} / \mathrm{cm}^{2}\right)$, Binjai $\left(35911,47 \mathrm{~kg} / \mathrm{cm}^{2}\right)$, Palembang $\left(35115,47 \mathrm{~kg} / \mathrm{cm}^{2}\right)$, terendah dari Sulawesi $\left(20098,9 \mathrm{~kg} / \mathrm{cm}^{2}\right)$.

Keteguhan patah (MOR) tertinggi terdapat pada jati super dari Lampung (528,74 $\left.\mathrm{kg} / \mathrm{cm}^{2}\right)$, Bengkulu $\left(469,91 \mathrm{~kg} / \mathrm{cm}^{2}\right)$, Kutai $\left(445,11 \mathrm{~kg} / \mathrm{cm}^{2}\right)$, Parung $\left(414,44 \mathrm{~kg} / \mathrm{cm}^{2}\right)$, Binjai $\left(409,78 \mathrm{~kg} / \mathrm{cm}^{2}\right)$, Palembang $\left(402,62 \mathrm{~kg} / \mathrm{cm}^{2}\right)$ Sulawesi $\left(243,74 \mathrm{~kg} / \mathrm{cm}^{2}\right)$.

Keteguhan tekan sejajar serat maksimum tertinggi yaitu jati super berasal dari Lampung $\left(326,29 \mathrm{~kg} / \mathrm{cm}^{2}\right)$, Bengkulu $\left(297,74 \mathrm{~kg} / \mathrm{cm}^{2}\right)$, Kutai $\left(267,74 \mathrm{~kg} / \mathrm{cm}^{2}\right)$, Parung $\left(259,25 \mathrm{~kg} / \mathrm{cm}^{2}\right)$, Binjai $\left(241,98 \mathrm{~kg} / \mathrm{cm}^{2}\right)$, Palembang $\left(225,15 \mathrm{~kg} / \mathrm{cm}^{2}\right)$ dan terendah terdapat pada jati super dari Sulawesi $213,79 \mathrm{~kg} / \mathrm{cm}^{2}$.

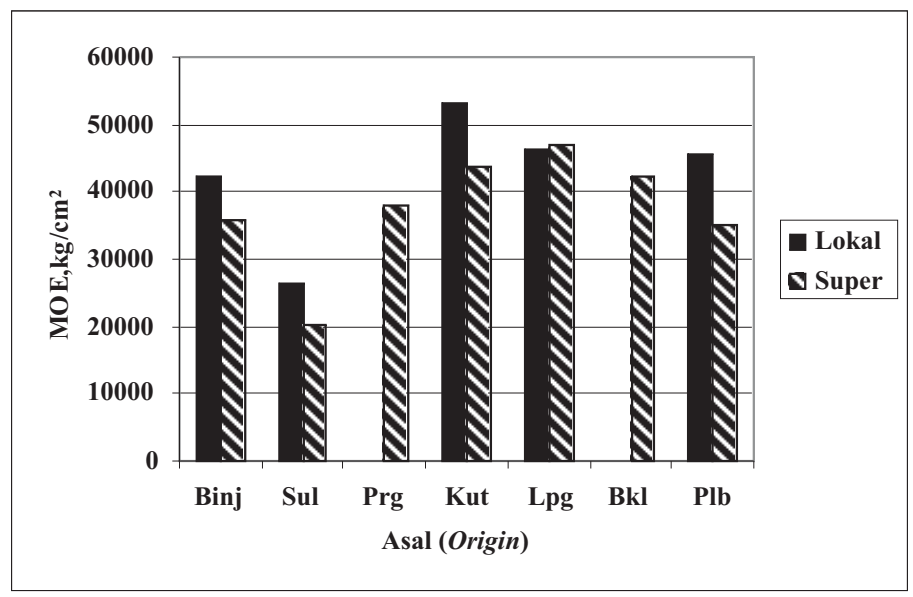

\section{Gambar 3. Histogram modulus elastisitas kayu jati yang diteliti Figure 3. Hystogram of modulus elasticity of teak wood tested}

Kekerasan sisi pada bidang radial tertinggi pada jati super terdapat pada jati super asal Bengkulu $\left(250,12 \mathrm{~kg} / \mathrm{cm}^{2}\right)$, Lampung $\left(247,75 \mathrm{~kg} / \mathrm{cm}^{2}\right)$, Parung $\left(238,75 \mathrm{~kg} / \mathrm{cm}^{2}\right)$, Palembang $225,50\left(\mathrm{~kg} / \mathrm{cm}^{2}\right)$, Kutai $\left(225 \mathrm{~kg} / \mathrm{cm}^{2}\right)$, Binjai $\left(200,75 \mathrm{~kg} / \mathrm{cm}^{2}\right)$, terendah terdapat pada jati super asal Sulawesi $\left(160,83 \mathrm{~kg} / \mathrm{cm}^{2}\right)$. Sedangkan Kekerasan sisi tangensial tertinggi terdapat pada kayu jati asal Lampung $\left(280,50 \mathrm{~kg} / \mathrm{cm}^{2}\right)$, Kutai $\left(260 \mathrm{~kg} / \mathrm{cm}^{2}\right)$, Parung $\left(258,50 \mathrm{~kg} / \mathrm{cm}^{2}\right)$, Bengkulu $\left(250 \mathrm{~kg} / \mathrm{cm}^{2}\right)$, Binjai $\left(237,67 \mathrm{~kg} / \mathrm{cm}^{2}\right)$, Palembang $\left(234,67 \mathrm{~kg} / \mathrm{cm}^{2}\right)$, dan terendah jati super dari Sulawesi $211 \mathrm{~kg} / \mathrm{cm}^{2}$. 
Pada Tabel 4 terlihat bahwa perbedaan jenis kayu jati hanya berpengaruh nyata pada kekakuan dan keteguhan tekan sejajar serat. Sedangkan lokasi tanaman berpengaruh nyata terhadap kekakuan dan kekuatan patahnya. Hal ini kemungkinan disebabkan karena keduanya masih tergolong tanaman muda. Sedangkan lokasi asal tanaman berbeda nyata pada keteguhan lenturnya. Dari hasil perbandingan nilai tengah perlakuan (lokasi) dengan uji Duncan (Herena, 1982), ternyata hanya kekuatan lentur statis kayu jati dari Sulawesi yang berbeda nyata terhadap kayu jati dari Parung, Binjai, Lampung, Bengkulu, Kutai dan Palembang. Kekuatan lentur statik jati dari daerah selain Sulawesi tidak menunjukkan perbedaan yang nyata.

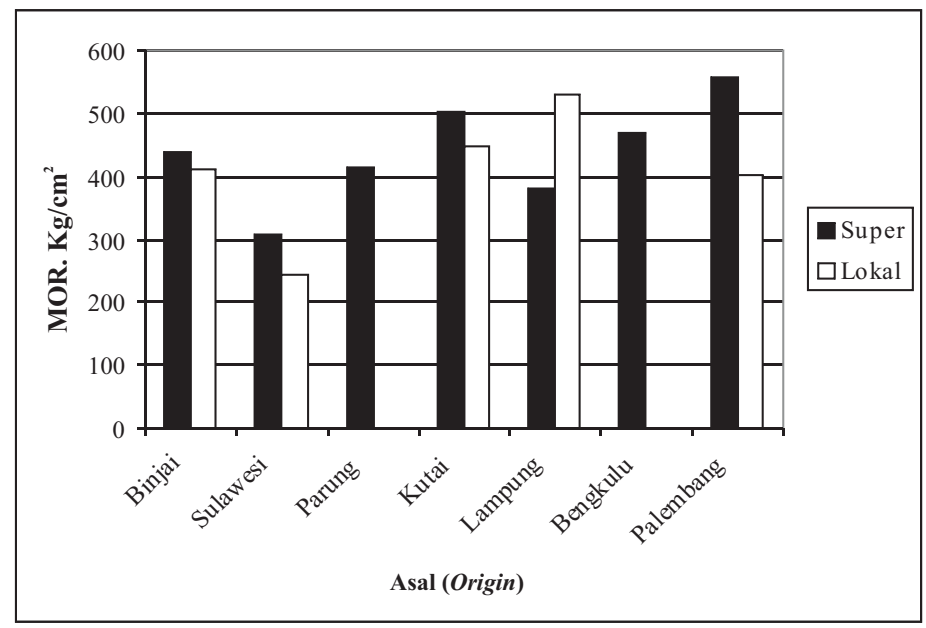

Gambar 4. Histogram modulus patah kayu jati yang ditelti Figure 4. Hystogram of modulus of rupture teak wood tested

Tabel5. Sidik ragam pengaruh jenis kayu jati dan lokasi tanaman terhadap sifat kekuatan kayu

Table 5. Analysis of variance of type and source of plant effect to specific gravity of teak wood tested

\begin{tabular}{|c|c|c|c|c|c|c|c|}
\hline $\begin{array}{c}\text { Sumber } \\
\text { keragaman } \\
\text { (Source of } \\
\text { variance) }\end{array}$ & \multirow{2}{*}{$\begin{array}{c}\mathrm{Db} \\
(d f)\end{array}$} & $\mathrm{MPL}$ & $\mathrm{MOE}$ & MOR & $\mathrm{C} / /$ & KEK-R & KEK-T \\
\cline { 3 - 8 } $\begin{array}{c}\text { Perlakuan } \\
\text { (Treatment) }\end{array}$ & 11 & $\mathbf{1 6 3 5 6 . 5 0 *}$ & $\mathbf{2 7 4 0 5 9 7 6 8 . 9 *}$ & $\mathbf{2 8 3 6 3 . 1 7 *}$ & $\mathbf{7 9 9 1 . 5 0 *}$ & 2950.88 & 1861.81 \\
\hline Galat (Error) & 46 & 3506.46 & 93945920.14 & 6469.43 & 1366.74 & 3024.32 & 2838.25 \\
\hline Total & 57 & & & & & & \\
\hline
\end{tabular}

Keterangan (Remarks) : * = Berbeda nyata pada tingkat nyata 95\% (significantly different at 95\% level) 
Berdasarkan nilai berat jenis yang dihitung dari berat dan volume kering udara serta kekuatan, kayu jati yang diteliti dapat digolongkan dalam kelas kuat seperti disajikan pada Tabel 6. Tabel tersebut menunjukkan bahwa pada umumnya kayu jati lokal maupun super tergolong kelas kuat III-IV dan ternyata lebih rendah bila dibandingkan dengan hasil penelitian Martawijaya et al. (1981) yang mempunyai kelas kuat II. Hal ini disebabkan karena jati yang diteliti umurnya jauh lebih muda (4-7 tahun atau KU I), sedangkan jati yang diteliti oleh Martawijaya et al. (1981) adalah jati yang sudah masak tebang berumur di atas 50 tahun. Hal ini didukung oleh pendapat Senft (1986) dalam Martawijaya (1990), bahwa pada tanaman muda yang banyak mengandung kayu remaja, umumnya memiliki berat jenis, modulus patah dan modulus elastisitas yang lebih kecil dari pada kayu sejenis dari hutan alam yang umumnya berumur lebih tua. Perbedaan sifat pada kayu hutan tanaman yang mengandung banyak kayu remaja itu terutama disebabkan oleh perbedaan berat jenis. Haygreen dan Bowyer (1982) mengemukakan bahwa kekuatan kayu berhubungan langsung dengan nilai berat jenis, semakin tinggi berat jenis, semakin tinggi nilai-nilai MOR, keteguhan pukul, kekerasan sisi dan keteguhan tekannya.

Tabel 6. Kelas kuat kayu jati yang ditelti Table 6. Strength classification of teak wood tested

\begin{tabular}{|l|c|c|}
\hline \multicolumn{1}{|c|}{ Asal (Origin) } & Lokal (Local) & Super \\
\hline Sumatra Utara & III & III \\
\hline Sulawesi Selatan & IV & IV \\
\hline Jawa Barat & - & III \\
\hline Kalimantan Timur & III & III \\
\hline Lampung & IV & III \\
\hline Bengkulu & - & IV - III \\
\hline Sumatra Selatan & III & III \\
\hline
\end{tabular}

Keterangan (Remarks): - = Tidak ada data (No data)

\section{KESIMPULAN DAN SARAN}

\section{A. Kesimpulan}

Penelitian sifat fisis dan mekanis kayu jati super dan lokal yang berasal dari beberapa daerah penanaman dapat disimpulkan sebagai berikut:

1. Berat jenis basah kayu jati super lebih tinggi dibandingkan dengan berat jenis basah kayu jati lokal. Berat jenis tertinggi terdapat pada kayu jati super yang berasal dari Binjai, sebaliknya berat jenis yang terendah berasal dari Maros, Sulawesi. Lokasi tempat tumbuh tidak memberikan perbedaaan nilai berat jenis.

2. Jati lokal yang berasal dari Palembang memiliki kelas kuat paling tinggi, sebaliknya jati super yang berasal dari Sulawesi memiliki kelas kuat paling rendah. 
3. Perbedaan jati super dan jati lokal terdapat pada sifat kekakuan dan keteguhan tekan sejajar serat, sedangkan asal tanaman berpengaruh terhadap sifat kekakuan dan kekuatan patahnya.

4. Kekuatan lentur statis kayu jati baik super maupun lokal dari Sulawesi berbeda dengan jati yang berasal dari Parung, Binjai, Lampung, Bengkulu, Kutai dan Palembang. Berdasarkan klasifikasi kekuatan kayu Indonesia, semua kayu jati yang diteliti tergolong kelas kuat IIIIV.

\section{B. Saran}

Agar data sifat fisis dan sifat kekuatan kayu sesuai dengan standar yang digunakan, disarankan penelitian dilanjutkan dengan menambah jumlah contoh uji yang mewakili lokasi dan variasi umur pohon. Contoh uji yang sama perlu disediakan untuk keperluan pengujian kekuatan kayu pada ukuran pemakaian (full scale).

\section{DAFTAR PUSTAKA}

ASTM. 1991. Annual Book of ASTM Standards 22. American Society for Testing and Materials. Philadelphia. USA

Berger, L.G. Den. 1923. Mechanische-technische eigenschappen van Indische Houtsorten. Tectona XIV. 358-36. Buitenzorg.

Brown, H.P., A.J.Panshin and C.C.Forsaith. 1952. Textbook of Wood Technology. Vol. II. Mc Graw-Hill Book Co. New York.

Haygreen, J.G. and J.L. Bowyer. 1982. Forest Product and Wood Science. An introduction. Iowa State Univ. Press. USA.

Herawan, T. dan L.H. Rina. 1996. Petunjuk teknis kegiatan kultur jaringan. Badan Litbang Kehutanan, Balai Penelitian dan Pengembangan Pemuliaan Benih Tanaman Hutan, Yogyakarta.

Herena, P. 1982. Perbandingan antar nilai tengah perlakuan dan masalah-masalah data. Pusat Pengolahan Data dan Statistik Pertanian. Badan Litbang Pertanian.

Karnasudirdja, S., Kurnia S. dan R. Kusumodiwiryo. 1974. Pedoman pengujian sifat fisik dan mekanik kayu. Publikasi Khusus No. 20. Lembaga Penelitian Hasil hutan. Ditjen Kehutanan. Dept. Pertanian. Bogor.

Martawijaya, A. , I. Kartasudjana, K. Kadir dan S. Amongprawira. 1981. Atlas Kayu Indonesia Jidlid I. Balai Penelitian Hasil Hutan. Badan Litbang Kehutanan. Bogor, Indonesia. Pp 42-47.

Martawijaya, A. 1990. Sifat dasar beberapa jenis kayu yang berasal dari hutan alam dan hutan tanaman. Proceedings Diskusi Hgutan Tanaman Industri. Jakarta, 13-14 Maret 1990. Badan Litbang Kehutanan, Jakarta.

Oey, D. S. 1964. Berat Jenis Kayu-kayu Indonesia dan Pengertian dari Berat Kayu Untuk Keperluan Praktek. Pengumuman LPHH No. 1. Bogor. 